\title{
THE AMERICAN INSTITUTE OF INTERNATIONAL LAW
}

In an article devoted to the American Institute of International Law which appeared recently in the Revue Générale de Droit International Public, ${ }^{2}$ the distinguished French publicist, Monsieur de Lapradelle, said: "For the moment, it is only a purpose, but of the kind that, as soon as conceived, is exccuted. It is only a proposition, but of the kind that, as soon as formulated, is accepted. In short, it is only a project, but of the kind that, as soon as formed, is realized." The association so warmly commended by Professor de Lapradelle has indeed come into existence. It was declared founded on Ortober 12, 1912.

It will perhaps be interesting to give a brief sketch of the origin of the new Institute, and the steps taken to sesure its organization before attempting to outline in summary form its field of action. The idea originated with Mr. Alejandro Alvarez, Counsellor of the Ministry of Foreign Affairs of Chile, member of the Permanent Court of Arbitration of The Hague, and Mr. James Brown Scott, member of the Institute of International Law, technical delegate to the Second Hague Peace Conference, and formerly solicitor for the State Department of the United States, in the course of an interview at. Washington, in June, 1911. They were discussing the relations which should, but unfortunately do not, exist betwcen the Republics of the Western Hemisphere, and it occurred to them that the field of international law furnished a common ground of contact, as well as of social and intellectual co-operation. The political relations of the various countries are matters for the foreign offices of the respective countriss to determine and control; the commercial relations for the foreign offices and the men of affairs; the educational relations for the universities and scientific conferences; but no steps heretofore had been taken unofficially, so far as they knew, to bring together the publicists who, separated by vast distances, to which Americans are accustomed, and the frontiers of their respective countries each with special interests, nevertheless were beset with the trouble-

${ }^{2}$ Vol. 19 (1912), pp. 1-VII 
some and perplexing question of international law and the principles of justice which should dominate foreign relations, if their respective countries were to live and grow in that peace and harmony which become members of the society of nations. As a result of this interview they decided to address a confidential note to their friends in the Republics of Latin America, and on October 10, I9II, a note was sent explaining the nature and scope of a proposed Institute of International Law similar to, but not wholly identical with, the Institute of International Law, which has rendered such distinguished service to the world at large. The replies to the note of October 10, I9II heartily endorsed the project, and its promoters were greatly encouraged by the promise of co-operation which every reply contained. The note called attention to the solidarity which exists between the states of the New World, due in large part to the fact that America is, geographically speaking, separated from the Old World as well as from its political traditions; that to preserve this solidarity arising fiom the nature of things and from the history of the American countries, and to develop what may be called the American conscience, political bonds are as impossible as they are unsatisfactory; that the relations which should exist between the republics can only be determined by scientific study and co-operation; that these could best be brought about by the creation of an Institute which should study the principles of international law, examine American problems and situations in the light of international law, and where it was lacking or inadequate, to develop such principles, based, however, upon the apirit if not the letter of the sysiem of international law to which all states are necessarily partics. It was felt, however, that the proposed Institute should attempt not merely to define and give precision to rules of international law; to state and decide what may be called American problems by its application; but to popularize international law in all parts of the Western Hemisphere by securing the establishment of national or local societies of international law in every American capital, so that an enlightened public opinion might be created, which would in time insist that intercourse between American states and diffe rences which may arise between them, be determined by the rules of law and justice.

The proposers of the Institute were unwilling to trust their 
own judgment, although approved by their friends in Latin America. They felt that they might be unconsciously the victims of enthusiasm. They, therefore, addressed representative members of the Institute of International Law, whose experience and detachment would enable them to weigh rightly the benefits reasonably to be expected from such an Institute and the difficulties in the way of its creation. The members consulted were apparently as enthusiastic as the American publicists, as is evidenced by the articles or opinions they wrote, which have appeared in the Revue Generale de Droit International Public. The mere enumeration of their names is imposing and is a guarantee of the usefulness, indeed one might almost say, the necessity of such an institution: von Bar, Catellani, Dupuis, Fauchille, Gram, Hegerup, Lammasch, de Lapradelle, Lawrence, von Liszt, de Louter, Oppenheim, Pillet, Politis, Albéric Rolin, Weiss, Westlake. Opinions from Messrs. Asser, Holland and others were received too late for publication, but they will be included in a brochure to be issued by the new Institute containing all documents relating to its origin, nature and organization.

Thus encouraged, Messrs. Alvarez and Scott drafted a constitution and by-laws of the Institute, which were sent under cover of a confidential note, dated Iuly 4, 1912, for the consideration of the American publicists to whom the first communication had been sent. The letter of transmission requested the gentlemen thus addressed to sign and return a copy of the constitution and by-laws, if these documents met with their approval, and to authorize the proposers of the Institute to constitute a temporary organization. The approval and authorization were given, and on October 12, 1912, the new Institute was declared founded, with the following temporary officers: Honorary President, Mr. Elihu Root; President, Mr. James Brown Scott; Secretary General, Mr. Alejandro Alvarez; Treasurer, Mr. Iuis Anderson.

The constitution and by-laws were based upon those of the Institute of International Law, with such modifications as were necessary to apply them to an institution of a somewhat different character. In speaking of the aims and purposes of the two institutes, the note of July 4, 1912, said:

"The aims and objects of each Institute are largely indentical; but in the formal statement of the aims and objects of the Amer- 
ican Institute, the part that treats of war is of secondary importance, as the proposers believe that the principles of international law are generally applicable and should be studied and developed so as to maintain the status of peace, which so fortunately exists between the American Republics. The proposers of the Institute also believe that it can best serve the cause of international law by devoting itself primarily, if not exclusively, to a consideration of the principles of law and justice which regulate the intercourse of nations, more particularly the American Republics; and that the Institute will perform the greatest possible service to humanity by considering the various means and agencies and by devising the machinery by which the normal relations of nations, based upon law and justice, may be maintained, instead of dissipating its energy by seeking to regulate war or to lessen its hardships. Other scientific bodies and writers of authority may be trusted to consider warfare in its various aspects. The American Institute may well take peace and peaceful relations for its province, although it may properly discuss questions of war, the rights and obligations of belligerents, and neutrality:"

An examination of the constitution shows that the American Institute is democratic and that it rests upon the principles of federation-democratic in the sense that it will be composed of an equal number (five) of publicists from each of the American states, and that they will not be selected arbitrarily by the Institute itself, but by the publicists composing the national or local societies of international law, to be founded in the capital of each of the Amcrican countries. It is federative in the sense that the national or local societics are affiliated with it, and that the members of the Institute recommended by the national or local societies can properly be said to represent them. The Institute is not to meet regularly in any one country, although it may have permanent headquarters, and it is provided by the constitution that the members of the national or local societies become as of right associate members of the Institute by the payment of the annual dues. Following the precedent of the older institutions, the members determine the policy of the Institute, and the associate members participate in its scientific proceedings and discussions.

In announcing the formation of the American Institute to the American publicists to whom the various communications 
were addressed and who are considered its charter members, Messrs. Alvarez and Scott took occasion to state at considerable length the objects of the Institute, the means by which they were to be attained, and to indicate not only its relations to the older Institute, but the role it may be expected to play in the development of international law and the betterment of international relations in the Western Hemisphere. The object of the American Institute is declared to be to discover the means of assuring peace and to strengthen the bonds of solidarity which nature and history have created between these states. To obtain and to maintain peace, the founders of the Institute declare it necessary to educate public opinion and to quicken its sense of justice, as well as to subject existing international relations to juridical regulation. It is next stated that the new Institute will endeavor to aid in the scientific development of international law by determining its principles and giving clearness and point to its rules, at present vague or ill-defined, when not non-existent. Bearing in mind the needs of actual life, the ideals of justice, and the principle of solidarity, attention is next called to the fact that the geographical situation, the history, and the political life of the states of the Western Hemisphere have created special problems and called into being peculiar situations. As this matter is one of considerable importance, it is well to quote the exact language of the note on this point:

"In the solution of these problems and in the examination of these conditions, the gencral principles universally accepted must be applied, when possible. But, in default of such application, it will be proper to enlarge and even to develop these principles, following the concept of justice and keeping in mind the express or tacit desires of the American States.

"This aspect of international law, which may be called American, in no way implies a desire on the part of the Institute to create a special law for its continent, different from universal international law. The new Institute will not be constructing a system of its own in regulating the problems and conditions which interest the States of the New World, any more than the PanAmerican Conferences have done so. The States of America intend that international law shall keep its true physiognomy and its universal character; but it is also their bounden duty to solve 
together international problems which are clearly American and which have thus far remained unsolved. We are happy to state that our eminent European colleagues who have been kind enough to encourage us in our work, have expressed an opinion upon this point which is in conformity with ours."

The note calls attention to the advisability of securing the preparation by and for each state of the American continent, of digests of international law similar to, but less elaborate than Professor Moore's monumental International Law Digest. The preparation and publication of such digests will powerfully aid the codification of international law; but even although codified, it will be necessary to interpret and to apply the law to concrete cases. The best and most acceptable way to interpret and apply the law is, in the opinion of Messrs. Alvarez and Scott, by means of a permanent court of justice, as proposed, but not actually established by the Second Hague Peace Conference, a court of justice "of free and easy access, composed of judges representing the different juridical systems of the world and capable of assuring continuity of arbitral jurisprudence."

"Finally, it will be the purpose of the Institute to form and direct fundamentally the public opinion of the American States by becoming, as much as possible, the organ of the juridical conscience of their continent. Without public opinion, there can be no true international law. International law will find its real support in public opinion rather than in force, for public opinion requires that the law which is established shall be applied everywhere. With this end in view, the by-laws of the new Institute provide for the establishment of national socicties, which will be composed of an unlimited number of nembers. One such society has already been founded in Mexico, and several are in process of formation in other countries. It is our earnest hope that the charter members of the Institute in each State will direct all their efforts to create at once this indispensable organ."

Such are in bricf the aims and purposes of the American Institute of International Law.

The Institute is created and it will enter upon its work as soon as arrangements can be made for its opening session at Washington. This will necessarily require time and patience, because of the great distance which its members must travel, and the dif- 
ficulty which will no doubt be experienced in fixing a suitable date. In the meantime, the officers have decided to issue certain publications. As above stated, the various documents relating to theorigin, nature and organization of the Institute will be published in a brochure and distributed to the members and associates of the Institute of International Law and to the charter members of ${ }^{\circ}$ the new Institute. This small volume will show the aims and purposes of the founders of the American Institute, and the care. and deliberation with which they have accomplished their task. It will also show the friendly spirit in which the members of the Institute of International Law have welcomed its foundation,. which will in itself be an incentive not to disappoint their expectations. As a tribute to the Institute of International Law as well. as to furnish safe and sure models for the guidance of the members. of the newer Institute, it has been determined to collect and to publish in the near future the resolutions and projects of the olderInstitute from its organization in 1873 . Copies of this valuablecollection will be sent, with the compliments of the American Institute, to the members and associates of the Institute of International Law, and will be of great value to the members of the new Institute, and to students of international law in all quarters of the globe.

As indicating the spirit which has animated its founders,. Mr. Root's addresses delivered in Latin America will be published in English and in Spanish and given the widest possible circulation. The new Institute will as soon as possible begin thepublication of the treaties, conventions, and international agreements concluded by the American States with one another, and this valuable publication will include the laws, regulations and ordinances of each of the American Republics, insofar as they affect or concern international law or international relations. It is proposed to issue such a collection annually in order that students, scholars and men of affairs may have at their disposal a record of each year's achievement.

It is not considered necessary to establish a journal of international law to serve as the organ of the American Institute, as. it is believed that: the Spanish edition of the American Journal' of International Jaw can, with slight modifications, be made an. acceptable organ of communication. 
In closing the note of October 12, 1912, announcing the formaion of the American Institute, the founders of the Society used language which may fittingly close this article.

"Finally, Mr. Elihu Root is specially entitled to our profound gratitude. As statesman and publicist, having ever at heart the promotion of peace and harmony among the States of the New World, the eminent juris-consult has not hesitated to attach himself to our cause. He heartily commended our idea, we have his support without reservation to our project; he has given us themost striking proof of his sympathy by accepting the honorary presidency of the American Institute of International Law. The authority of his name is for us the surest guarantee of success."r

Washinglon, March, ror3. James Brown Scolt. 